\title{
Improving bypass performance and passage success of Atlantic salmon smolts at an old fish-hostile hydroelectric power station: a challenging task
}

\author{
Michaël Ovidio ", Séverine Renardy, Arnaud Dierckx, Billy Nzau Matondo, Jean- \\ Philippe Benitez
}

UR-FOCUS, Management of Aquatic Resources and Aquaculture Unit, Laboratory of Fish Demography and Hydroecology, University of Liège, Belgium

\section{A R T I C L E I N F O}

\section{Keywords:}

Fish passage

Downstream migration

Hydroelectricity

Fish telemetry

Individual behaviour

\begin{abstract}
A B S T R A C T
Old hydroelectric power stations often provide unsafe migration routes to fish, apart from passing through mobile gates during high flow. The installation of retrofitted bypass is considered to be a potential solution to improve fish passage at such old structures, but their performances are often insufficient. In the Amblève River (Belgium), a mobile $3.3 \mathrm{~m}$ high dam feeds two principal Francis turbines $\left(12+14 \mathrm{~m}^{3} \mathrm{~s}^{-1}\right)$ and is equipped with three mobile gates, a modern vertical slot upstream fish pass and a retrofitted downstream bypass functioning at a very low flow ( $1 \%$ of maximum turbined flow). A bypassed river section (length $8.4 \mathrm{~km}$ ) downstream of the dam was set at $3 \mathrm{~m}^{3} \mathrm{~s}^{-1}$ and supplies a Francis microturbine. From 2015 to 2016, we used 1150 hatchery Atlantic salmon smolts (Salmo salar), and we placed antennae with automatic radio-frequency identification (RFID) stations to analyse the migration routes used $(n=5)$. We tested the attraction efficiency and the performance of the bypass with and without the placement of a guidance system at the entrance and examined the proportion of smolt passage at the different migration routes under three functioning configurations. The placement of the guidance system markedly improved the attraction efficiency and the overall passage efficiency. The median time spent at the entrance of the bypass was from 7 to $12 \mathrm{~min}$, and the time spent near the entrance of the bypass was less than $1 \mathrm{~h}$ for $67.1 \%$ (release 1), $88.2 \%$ (release 2) and 63.7\% (release 3) of the smolts. During the three release events, the smolts arrived near the entrance of the bypass mostly during the dusk and dark periods (87.5\%, 96.0\% and $95.5 \%$, for releases 1,2 and 3, respectively). In a configuration without opening a mobile gate, the bypass was the most used migration route, followed by the microturbine and the main turbine. Stopping the microturbine and opening a mobile gate has consequences of making it the first choice of passage followed by the main turbine and the bypass. The re-establishment of safe and quick downstream migration has to be considered with a holistic view of the functioning of the hydroelectric powerstation.
\end{abstract}

\section{Introduction}

Physical obstructions are recognized as major factors influencing the migrations, population structures, spawning success and recruitment of freshwater organisms by preventing or limiting access to formerly available functional habitats (Fullerton et al., 2010; Nunn and Cox, 2012; Benitez et al., 2015; (Ovidio and Philippart, 2002)Ovidio et al., 2020). In addition, hydropower turbines represent a major problem for downstream migrating fish, causing direct or delayed mortality due to passage through turbines, as well as delays for fish that need to migrate long distances (Fjeldstad et al., 2012; Buysse et al., 2015). Multiple hydroelectric dams along migration routes may lead to important cumulative mortality rates (Verbiest et al., 2012; Marohn et al., 2014). The Atlantic salmon (Salmo salar Linnaeus, 1758) has been one of the species most affected by river fragmentation, with consequent major reductions and even the extinction of some strains in different river basins in Europe and America (Philippart et al., 1994; Parrish et al., 1998; Larinier, 2001; Thorstad et al., 2012). The cumulative impact of the succession of multiple hydropower stations on downstream migration may be considerable and is a major problem for smolts that have to migrate long distances in rivers (Thorstad et al., 2012, 2017). This is especially due to the narrow smolt migration window that prevents the escape of part of the population to the ocean in time due to migration delays (McCormick et al., 1998; Marschall et al., 2011; Thorstad et al.,

\footnotetext{
* Corresponding author at: UR-FOCUS, Biology of Behaviour Unit, Laboratory of Fish Demography and Hydroecology, University of Liège, 22 Quai Edouard Van Beneden, B-4020, Belgium.

E-mail address: m.ovidio@uliege.be (M. Ovidio).
} 
2012) and, as a consequence, reduces the subsequent number of returning spawning adult salmon in rivers the following years (Thorstad et al., 2017).

Interest in facilitating downstream migration at hydropower stations has generally increased in recent years (Katopodis and Williams, 2012; Silva et al., 2018). Appropriate mitigation measures for turbine entrainment at hydroelectric power station has focused on the installation and operation of fish protection systems. In harmful hydroelectric stations, fish-friendly trash-racks as well as downstream bypasses have been developed and tested to prevent smolts from entering the turbines and to mitigate the negative effects of hydropower stations on migration (Coutant and Whitney, 2000; Larinier and Travade, 2002; Albayrak et al., 2018; Calles et al., 2012; Fjeldstad et al., 2018; Klopries et al., 2018; Tomanova et al., 2018; Tétard et al., 2019; Larinier et al., 2020; Renardy et al., 2020). Fish-friendly turbines (e.g. the Archimedes screw; Brackley et al., 2018) may also be used to combine the advantage of electricity production and a potential safe migration route, but some studies have demonstrated their low attraction (Havn et al., 2017; Piper et al., 2018; Renardy et al., 2020) or provided new insights on the fishfriendliness of Archimedes hydrodynamic screws (Pauwels et al., 2020). Another challenge is to understand the selection of a migration route by smolts when they are confronted with multiple choices, combining both safe and unsafe routes (Renardy et al., 2020). A better understanding of the factors that guide the choice of a migration route and of its influence on the further success of migration is one of the challenging research topics to improve the escapement rate of smolts in highly fragmented rivers. Such studies would also be relevant to test and improve the performance of the downstream fish-passage devices. Despite efforts to measure fish guidance efficiency values and understand how fish react to various fish guidance structures, the successful design and operation of fish protection systems is an evolving science, largely because of the great diversity in the design, operation and hydraulic performance of fish guidance and bypass structures (Scruton et al., 2003). Given that the efficiency of downstream fish passage is strongly related to the specificity, configuration and typology of the hydroelectric site and the size of the river, there is a need to collect experiences from a wide range of situations to identify successful and more integrative solutions for the future.

In this study, we investigated the downstream migration behaviour of individual $S$. salar smolts at a hydropower station installed along the Amblève River (Meuse basin, Belgium), which is topologically complex and offers four potential migration routes, including two unsafe (main Francis turbines and one Francis microturbine) and three safe (a retrofitted downstream bypass, a fish pass and three mobile gates) routes. The performance of the retrofitted bypass was evaluated in a previous study and was quantified as very poor (Ovidio et al., 2017a). The overall aim of this study was i) to test an improvement of the configuration of the retrofitted bypass in terms of attraction efficiency and passage performance and ii) to analyse the migration routes chosen by Atlantic salmon smolts with two different configurations of the hydropower station, by modifying the opening of the gates; and iii) to analyse the downstream migratory patterns and the swim speed of smolts once the hydropower station has been crossed and the influence of a $8.4 \mathrm{~km}$ long bypassed river section on their migration success. Observations were performed using RFID telemetry systems.

\section{Material and methods}

\subsection{Study site}

The Lorcé dam is situated in the grayling zone (Huet, 1949) of the Amblève River, a tributary of the Ourthe River within the river Meuse basin in Belgium (Fig. 1A). The Amblève is a typical medium-sized highland river with a median inter-annual flow of $19.3 \mathrm{~m}^{3} \mathrm{~s}^{-1}$. In the entire river, both the water quality and prevailing macro-invertebrate communities are currently indicative of good water quality $(>16 / 20$;
Public Service of Wallonia - AQUABIO). The Amblève river basin is, however, fragmented by several artificial physical barriers and is exploited by seven major hydroelectric power plants (Fig. 1B).

The Lorcé dam creates a 50,000 $\mathrm{m}^{3}$ reservoir (1.1 km long), which feeds a forced pipeline arriving at the Heid de Goreux hydroelectric power station (7 MW; two Francis turbines, maxima are 12 and $14 \mathrm{~m}^{3}$ $\mathrm{s}^{-1} ; 40 \mathrm{~m}$ Delta height [Dh]) (Figs. 1 and 2). The intake dam has two mobile gates (each $12 \mathrm{~m}$ wide for discharging water during high flow) and an evacuating gate ( $3 \mathrm{~m}$ wide, for evacuating water during maintenance), creating a $3.3 \mathrm{~m}$ Dh drop. The bypassed river section (length $8.4 \mathrm{~km}$ ) downstream of the dam was set at $3 \mathrm{~m}^{3} \mathrm{~s}^{-1}$ and turns a Francis microturbine ( $85 \mathrm{~kW}$ maximum power). All the turbines are fed through a large trash-rack made of vertical bars spaced $41 \mathrm{~mm}$ apart (Figs. 1 and 2). Since its construction in 1932, the Lorcé dam has been impassable for fish outside of rare periods (e.g. during repair works or high floods when gates are opened). At the end of 2007, the dam was equipped with a 500 $1 \mathrm{~s}^{-1}$ pool-type fish pass, with a fish trap that was monitored during six consecutive years. During a previous investigation, 1513 individuals belonging to 22 fish species were monitored with a fish trap at the upstream end of the fish pass (Benitez et al., 2015). In 2012, a downstream migration bypass was installed in the prolongation of the trash-rack (Figs. 1 and 2) at a specific location that was determined based on Atlantic salmon smolts telemetry studies. The recommended operating flow was fixed at $6501 \mathrm{~s}^{-1}$ (based on Courret and Larinier, 2008), but the actual configuration allows only $3001 \mathrm{~s}^{-1}(0.6 \%$ of the maximum flow turbined) from a rectangular $0.7 \times 1.2 \mathrm{~m}$ entrance, of which $0.7 \times 0.4 \mathrm{~m}$ is immersed. This deficit is due to the difficulty in perforating a cavity in the concrete structure of the dam for a preliminary configuration, as well as the absence of imposition to enable downstream migration when the dam was initially constructed. However, the water supply of the bypass depends on the water level upstream of the dam, and it may decrease during prolonged low water levels, when hydroelectricity is produced by hydropeaking.

The Atlantic salmon disappeared from the Meuse River basin in the 1930 s, and a restoration programme started in the early 1990s (Philippart et al., 1994). However, the population is still not self-sustainable, and a salmon hatchery is necessary to produce parrs and smolts for river restocking. On 21 April 2015 and 3 February 2016, a total of 1150 smolts from the Erezée hatchery (SPW/DNF) were surgically equipped with a $23 \mathrm{~mm}-0.6 \mathrm{~g}$ half duplex pit-tag (Texas Instruments) after anaesthesia (Eugenol, $0.2 \mathrm{ml} \mathrm{l}^{-1}$ ) and maintained in $2 \mathrm{~m}^{3}$ circular tanks in the hatchery before the study. We tested three different configurations of the power plant and 300 smolts were released at each date at $3.75 \mathrm{~km}$ upstream of the Lorcé dam (Fig. 1): 21 April 2015 (release 1) with a median size of $140 \mathrm{~mm}$ (range: $120-163 \mathrm{~mm}$ ), 11 April 2016 (release 2) with a median size of $134 \mathrm{~mm}(121-158 \mathrm{~mm}$ ) and 20 April 2016 (release 3) with a median size of $135 \mathrm{~mm}(120-159 \mathrm{~mm})$.

During release 1 , the gates were raised and the total flow was turbinated $\left(3 \mathrm{~m}^{3} \mathrm{~s}^{-1}\right)$ by the microturbine, resulting in a minimum flow downstream of the Lorcé power plant, and by one Francis turbine (14 $\mathrm{m}^{3} \mathrm{~s}^{-1}$ ) of the Heid de Goreux HPP. The entrance of the bypass was not equipped with the guidance system. During release 2 , the central gate of the Lorcé dam was lowered $40 \mathrm{~cm}$, allowing a $0.17 \mathrm{~m}$ underflow and an estimated flow of $2.3 \mathrm{~m}^{3} \mathrm{~s}^{-1}$ (Fig. 2). The microturbine of the dam was not functioning and the downstream bypass was not equipped with the guidance system. We must specify that the small gate close to the left bank can only be opened from the bottom and cannot be used to produce a surface water flow above the gate. At 50 and $25 \mathrm{~cm}$ from the entrance of the bypass, flow velocities are 0.14 and $0.36 \mathrm{~m} \mathrm{~s}^{-1}$, respectively. The mean surface flow velocity just at the entrance is $1.05 \mathrm{~m} \mathrm{~s}^{-1}$, and just before the dropping point (where water drops down, just before the point where fish are unable to return upstream and exit the bypass channel, $30 \mathrm{~cm}$ inside the guidance system), it is $1.6 \mathrm{~m} \mathrm{~s}^{-1}$ (Fig. 2). During release 3 , the gates were raised and a guidance system was placed at the entrance of the surface bypass for downstream migrating smolts (Fig. 2). The guidance system consists of a fixed device with a 

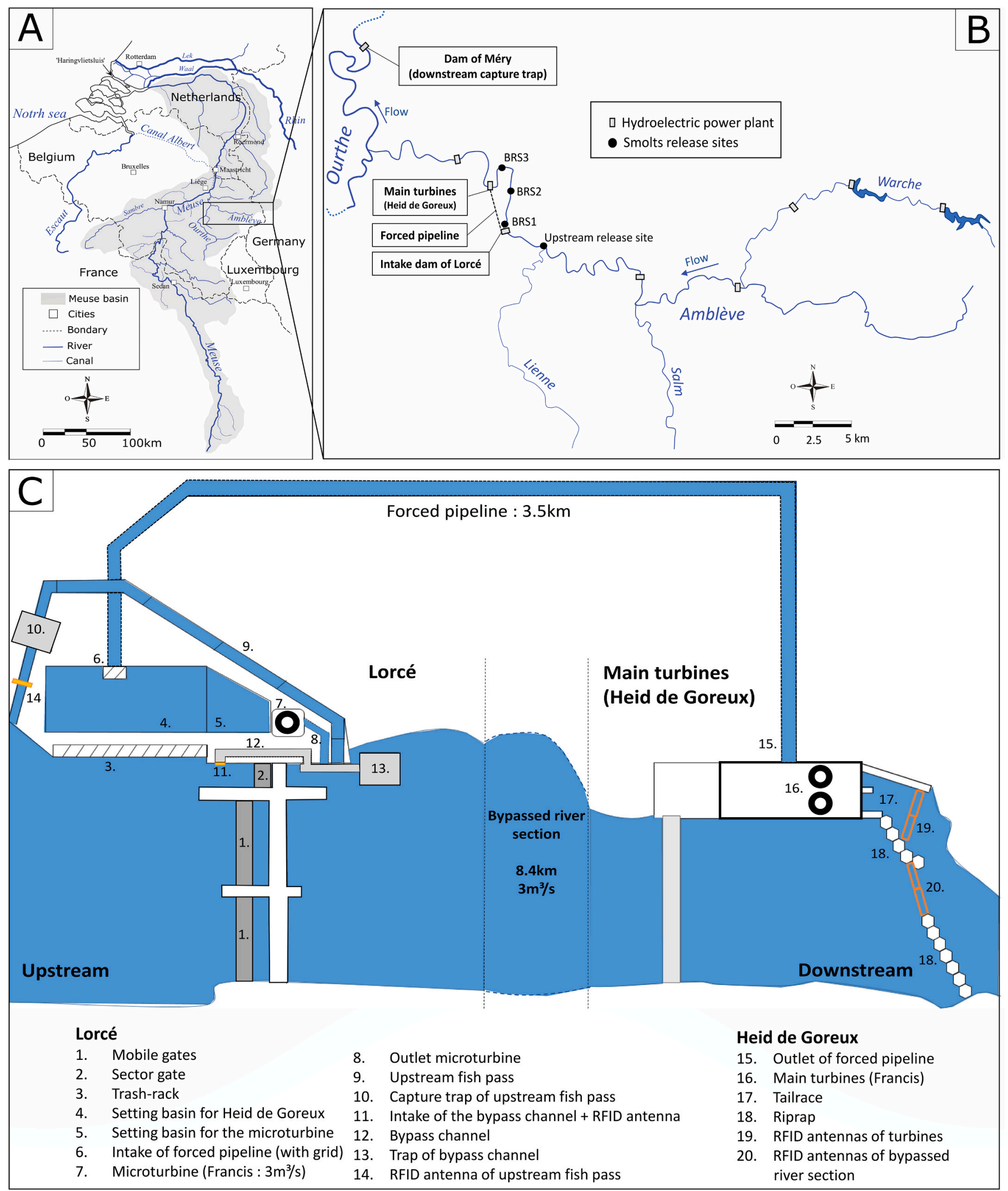

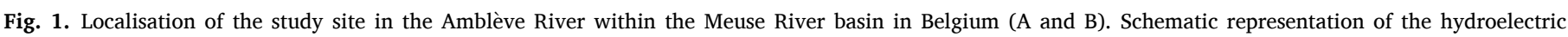

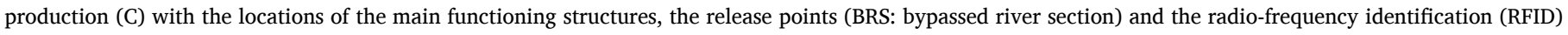
antennae used in this study. 

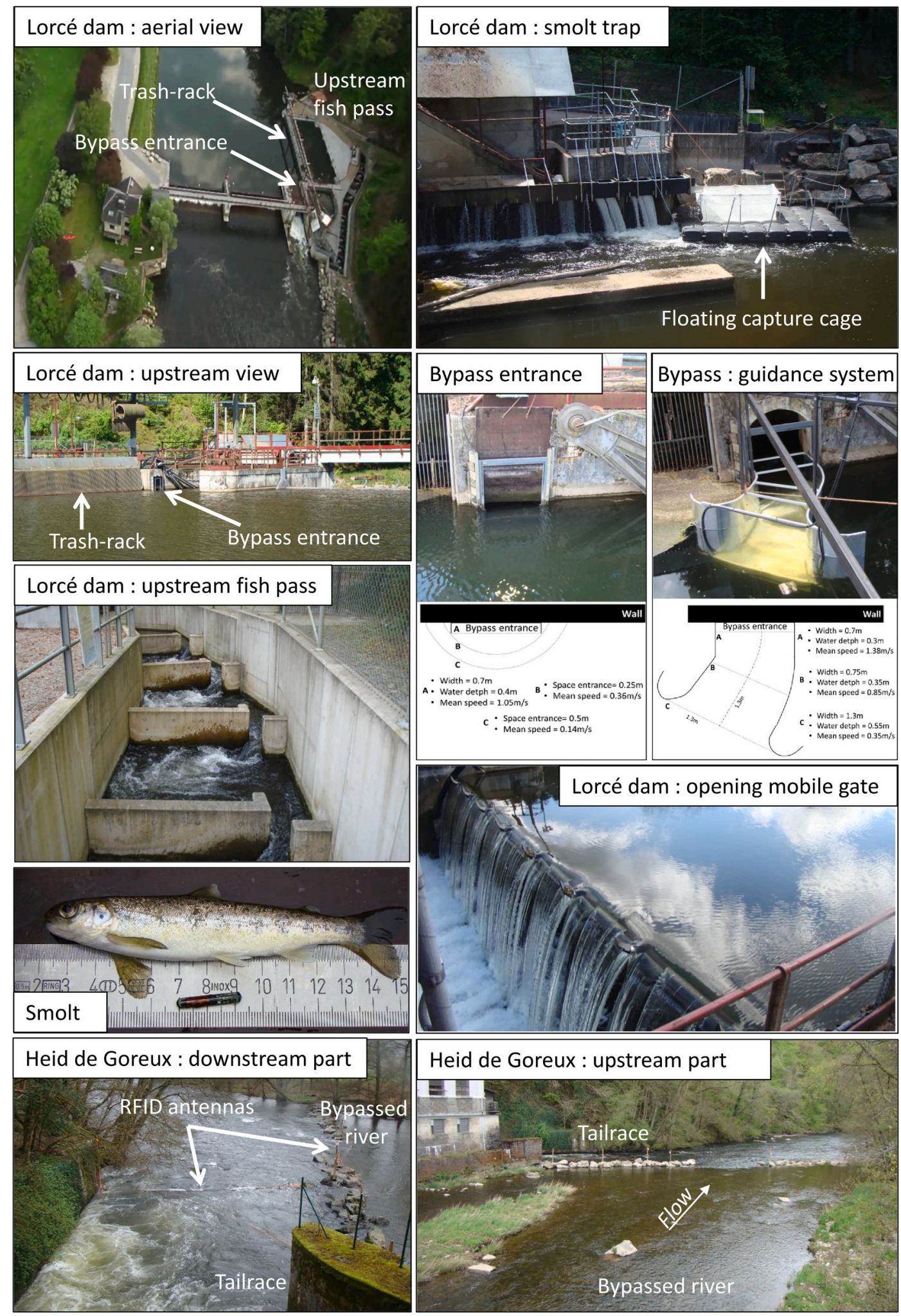

Fig. 2. Photographic representations of the production site, the upstream fish pass, the capture trap of the downstream bypass, the biological model and the tag used, the bypassed river section and the restitution area, the bypass entrance with or without the guidance system system as well as the associated flow velocities.

slight slope composed of a wide inlet and a narrow outlet. The current speed, which is low at the intake, is gradually increased while minimising detachment phenomena and turbulence due to its elliptical profile (Larinier and Boyer-Bernard, 1991). Due to the device, the flow velocity gradually increases and fish are less frightened while dissuading them from making a U-turn. This guidance system ( $1.3 \mathrm{~m}$ long) has been placed in line with the main current (initial width $=1.3 \mathrm{~m}$ and final width $=0.7 \mathrm{~m}$ ). The flow velocity gradually increases from the entrance $\left(0.35 \mathrm{~m} \mathrm{~s}^{-1}\right)$ to the end $\left(1.38 \mathrm{~m} \mathrm{~s}^{-1}\right)$ (Fig. 2). At the drop the water flow velocity is $1.6 \mathrm{~m} \mathrm{~s}^{-1}$. During the three release events, a mercury lamp 
was permanently placed above the bypass to illuminate its entrance. A previous study at the same site (Ovidio et al., 2017a) demonstrated this increases the attraction and overall bypass efficiencies of the bypass.

In addition, 200 smolts were released downstream of the Lorcé dam in 4 batches of 50 in order to test the escapement rate and the speed of the smolt in the $8.4 \mathrm{~km}$ bypassed river section: $n=2$ batches at $0.05 \mathrm{~km}$ of which $\mathrm{n}=1$ during release 2 with a median size of $135 \mathrm{~mm}$ (range: $125-150 \mathrm{~mm}$ ) and $\mathrm{n}=1$ during release 3 (median size $=135 \mathrm{~mm}$, range: $123-161 \mathrm{~mm}), \mathrm{n}=1$ batch at $3.8 \mathrm{~km}$ during release $3(136 \mathrm{~mm}$, $126-153 \mathrm{~mm})$ and $\mathrm{n}=1$ batch $5.8 \mathrm{~km}$ during release $3(132 \mathrm{~mm}$, $121-158 \mathrm{~mm})$.

\subsection{Detection system, smolt trap and behavioural metrics}

In 2015 , one antenna was placed at the entrance of the bypass. In 2016, a total of seven RFID antennae were installed at five locations of the production site (Fig. 2). Three simple pass-through antennae have been installed at the Lorcé dam (detection range of $\pm 0.3 \mathrm{~m}$ ):

- One at the entrance of the bypass $(0.8 \times 1 \mathrm{~m})$;

- One at the entrance of the guidance system $(1.4 \times 0.8 \mathrm{~m})$, during release 3 , in order to test the proportion of detections at the entrance of the guidance system and the entrance of the bypass and.

- One at the exit of the upstream fishway $(1.1 \times 1.5 \mathrm{~m})$, which constitutes a non-optimal but a potential downstream migration route.

The Heid de Goreux HPP was equipped with two pairs of passthrough side-by-side antennae in order to maintain a good detection range over the entire width of both channels:

- Two $(5.5 \times 0.6 \mathrm{~m})$ at the tailrace $($ width $=11 \mathrm{~m})$ of the main turbines and.

- Two $(5 \mathrm{~m} \times 0.6 \mathrm{~m})$ at the end of the bypassed river section (width $=$ $10 \mathrm{~m}$ ) to detect the smolts that use the gates, the upstream fishway, the bypass as migration route or the microturbine as migration route.

The placement of these antennae was determined to evaluate the efficiency of the bypass and to analyse the use of the different migration routes, which are: 1 ) the downstream bypass, 2) the microturbine of the Lorcé dam, 3) the gates of the Lorcé dam, 4) the fishway and 5) the main turbines after the entrance in the forced pipeline (Figs. 1 and 2).

The antennae were connected to $\operatorname{CIPAM} \AA$ (Clermont-Ferrand, France) detection stations (1-2 antenna(e) connected to one station) that constantly listened to the potential presence of tagged smolts approaching and/crossing the antennae. The detection time and code of each tagged fish was stored in the memory of the RFID station before downloading to a computer. The same tag may be detected every $5 \mathrm{~s}$ while it remains in the detection area of the antenna. As a constraint with RFID telemetry, the antenna was not able to detect two tags simultaneously: the time between the detection of two different tags is limited to $0.5 \mathrm{~s}$. In addition, during every release event, a floating trap was placed downstream of the bypass. It consists of a floating cage equipped with fine mesh net $(8 \mathrm{~mm})$ (Fig. 2), which was monitored every day after each release and allowed us to compare detection at the entrance of the bypass and effective use of the bypass as a migration route.

The utilisation of a migration route can be deduced based on the detections at the antennae and smolt captures in the trap. The use and the performance of the downstream bypass was quantified using different passage metrics (Ovidio et al., 2017a).

(1) Arrival activity time: the hourly time of only the first detection of individual smolts detected by the RFID antennae of the study site.

(2) Search activity time: the collection of hourly time of all the detections of all individual smolts detected by the RFID antenna.
(3) Searching delay: the time period between the first and the last detection at the hydropower station for each detected individual;

(4) Minimal bypass attraction efficiency: the percentage of individual smolts detected at the entrance of the bypass by the RFID station compared with those released upstream. The smolts may have not reached the bypass due to predation or mortality, so this is a minimum estimate;

(5) Overall bypass passage minimum efficiency: the percentage of individual smolts captured in the bypass trap compared with the tagged fish that were released upstream; and.

(6) Adjusted bypass passage efficiency: the percentage of individual smolts captured in the bypass trap compared with the number of smolts that were detected (RFID) before at the entrance (with or without the guidance system).

At $42 \mathrm{~km}$ downstream of the Lorcé dam, in the Ourthe River, we also monitored a downstream bypass equipped with a trap (Renardy et al., 2020) during the study (location presented in Fig. 1). We used this monitoring to try to recapture smolts after their passage of the hydroelectric site of the Lorcé dam, to estimate migration speed and to determine whether undetected smolts at the Lorcé hydroelectric power station are potentially captured further in the Ourthe River at Méry. This trap was monitored every day in the morning ( $9 \mathrm{~h}-11 \mathrm{~h}$ ) during the study. The estimation of the migration speed from the tailrace of the main turbines to Méry was estimated by a supposed maximum arrival at 8:00 a.m. on the day of capture (as we know that smolt migration occurs mainly during the night in the Ourthe basin Ovidio et al., 2017a).

\subsection{Turbine function and environmental factors}

Turbine data (main turbines and microturbines), gate positioning and variations in the height of the Lorcé reservoir were made available to us by Electrabel, owner and operator of the hydroelectric complex. Water temperature (with $0.1{ }^{\circ} \mathrm{C}$ precision) was recorded with tidbit Onset ${ }^{\circledR}$ recorders placed at the Lorcé dam. Water flow was continuously measured in the main course of the Amblève and in the tributaries (data from SETHY and Aqualim - SPW).

\subsection{Data analysis}

The data violate normality assumptions (Kolmogorov-Smirnov, $p<$ 0.05 ), and thus we used nonparametric tests. Operating and environmental conditions (daily means) were compared between releases over a 10-day post-release period using the nonparametric Kruskal-Wallis (KW test). In order to analyse the effect of the hydropower station configuration on the use of the bypass, we compared minimal bypass attraction efficiency, overall bypass passage minimum efficiency and adjusted bypass passage efficiency between releases and the distribution using the Pearson chi square test. We corrected the numbers of smolts detected at Heid de Goreux by migration route including the effect of the bypassed river (rate of the number of undetected individuals compared to the number of individuals released downstream of the Lorcé dam) and the theoretical turbine mortality rates (Larinier and Travade, 1999). Pearson chi square tests were also used to test if the smolts changed their migration behaviour over time by comparing arrival activity time and search activity time between two periods (dusk/dark vs. dawn/day) where dawn and dusk represented periods of $2 \mathrm{~h}( \pm 1 \mathrm{~h}$ of sunrise and sunset hours, respectively). We tested the potential influence of the size of smolts (longer smolts have best swimming capacities) on the choice of migration routes using the KW test. When the KW test was significant, we used the post hoc Wilcoxon pairwise comparison with Bonferroni-Holm correction. We calculated migration speeds for the different sections and compared between migration routes using the KW test and the pairwise Wilcoxon test. We tested the difference in migration speeds between the total section (release site to Heid de Goreux) and the bypassed river section for smolts using the bypass and between the total 
section and the Heid de Goreux to Méry section for all smolts using the Wilcoxon test. The level of significance was set at 0.05 ; tests were carried out using the R statistical program (The R Foundation for Statistical Computing, Vienna, Austria, version 3.1.1.).

\section{Results}

\subsection{Environmental factors and turbine function}

For the period of 10-days post-release (Fig. 3), the median water flows for the 3 releases were respectively $11.1 \mathrm{~m}^{3} \mathrm{~s}^{-1}$ (range: 8.7-19.3 $\left.\mathrm{m}^{3} \mathrm{~s}^{-1}\right), 13.6 \mathrm{~m}^{3} \mathrm{~s}^{-1}\left(9.7-17.2 \mathrm{~m}^{3} \mathrm{~s}^{-1}\right)$ and $10.4 \mathrm{~m}^{3} \mathrm{~s}^{-1}\left(7.9-24.0 \mathrm{~m}^{3}\right.$ $\mathrm{s}^{-1}$ ) and the median water temperature was respectively $10.0{ }^{\circ} \mathrm{C}$ (8.5-11.9 $\left.{ }^{\circ} \mathrm{C}\right), 9.4{ }^{\circ} \mathrm{C}\left(8.6-10.3^{\circ} \mathrm{C}\right)$ and $8.5^{\circ} \mathrm{C}\left(5.6-11.2^{\circ} \mathrm{C}\right)$. The water flow, the water temperature, the ratio of flow by the bypass and the ratio of flow by the main turbines were not different between releases (KW tests: all $p>0.05$ ).

\subsection{Bypass use and performance}

Table 1 presents the bypass use and performance data for each release. During release 1 , among the 300 smolts released, 70 were detected near the entrance of the bypass and 32 were captured in the trap. This represents an attraction efficiency of $23.3 \%$, an overall bypass efficiency of $10.7 \%$ and an adjusted bypass efficiency of $45.7 \%$. During release 2, among the 300 smolts released, 76 were detected near the entrance of the bypass and 34 were captured in the trap. This represents an attraction efficiency $25.3 \%$, an overall bypass efficiency of $11.7 \%$ and an adjusted bypass efficiency of $44.7 \%$. During release 3 , among the 300 smolts released, 134 smolts were detected at the entrance of the bypass and 97 were captured in the trap. This represents an attraction efficiency of $44.7 \%$, an overall bypass efficiency of $32.3 \%$ and an adjusted bypass efficiency of $72.4 \%$. The efficiencies (attraction, overall and adjusted) were greater during release 3 compared with releases 1 and 2 (Pearson's $\left.\chi^{2}, p<0.001\right)$. However, if we consider only the 188 smolts detected by the antenna at the entrance of the guidance system, the attraction efficiency increases to $62.7 \%$ (significantly higher than releases 1 and 2 , Pearson's $\chi^{2}, p>0.05$ ) and the adjusted efficiency drops to $51.6 \%$ which is not significantly higher (Pearson's $\chi^{2}, p>0.05$ ) than during releases 1 and 2 (Table 1 ).

During the three release events, the smolts mostly arrived (first detection only) near the entrance of the bypass (Pearson's $\chi^{2}, p<0.001$ ) during dusk and dark periods (87.5\%, 96.0\% and 95.5\%, for releases 1, 2 and 3, respectively). The smolts' peak arrival occurred between 23:00 h and 00:00 $\mathrm{h}$ for the three release events (Fig. 4A). When considering the total number of detections of all individuals together (Fig. 4B), searching activity was largely dominant (Pearson's $\chi^{2}, p<0.001$ ) during the dusk and dark periods $(93.1 \%, 99.7 \%$ and $88.4 \%$, for releases 1,2 and 3 , respectively). Searching activity peaks were between 03:00 $\mathrm{h}$ and 04:00 $\mathrm{h}$ for releases 1 and 2 and between 00:00 $\mathrm{h}$ and 01:00 $\mathrm{h}$ for release 3 .

The median time spent at the entrance of the bypass for all detected smolts was $10 \mathrm{~min}$ (release 1), $7 \mathrm{~min}$ (release 2) and $12 \mathrm{~min}$ (release 3); there was no significant difference among releases (KW test: $\chi^{2}=3.53$, $\mathrm{df}=2, p=0.17$, Fig. 5). The time spent near the entrance of the bypass was less than $1 \mathrm{~h}$ for $67.1 \%$ (release 1 ), $88.2 \%$ (release 2) and $63.7 \%$ (release 3 ) of the smolts (Pearson's $\chi^{2}, \mathrm{p}<0.001$, Fig. 5). The time spent at the entrance of the bypass was not different between the smolts that used or did not use the bypass as migration route for releases 1 and 3 (Wilcoxon test, $p=0.32$ and $p=0.23$, respectively), but it was significantly greater for smolts of release 2 that used the bypass (Wilcoxon test, $p=0.02$ ).

Visual observations at the bypass entrance showed contrasting approach behaviour between the configuration with and without the guidance system. In the absence of the guidance system, smolts approached the bypass tail first and offered resistance by swimming against the flow just before the dropping point where they are unable to return upstream and exit the bypass channel. Smolts that actually enter the bypass are entrained and do not do so voluntarily (Supplementary Material A). With the guidance system (Supplementary Material B), a higher proportion of smolts approached the entrance of the bypass with less reluctance and many of them entered head first, even if some continue to hesitate just at the place where water picks down.

\subsection{Migration routes $u$ sed by the smolts}

During release 2 (Fig. 6), among the 300 smolts, 76 (25.3\%) were detected at the entrance of the bypass and $34(11.3 \%)$ used the bypass as a migration route; $15(5.0 \%)$ were further detected at the end of the bypassed river section. Five (1.7\%) smolts that approached the bypass and that were not captured in the trap were finally detected at the end of the bypassed river section and used the mobile gate as a migration route. Eleven $(3.7 \%)$ smolts that approached the bypass were finally detected in the tailrace of the main turbines. This means that at least $21 \%$ of the smolts that approached the bypass finally changed their choice of
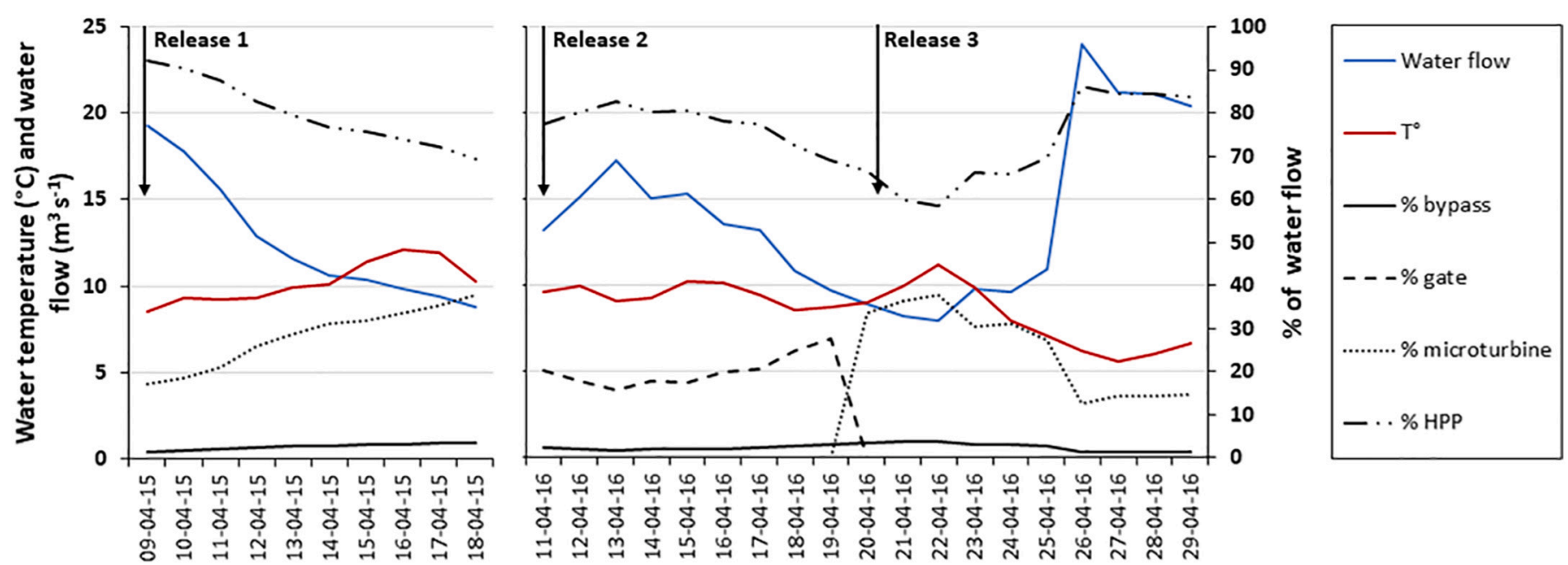

\section{Date (dd-mm-yy)}

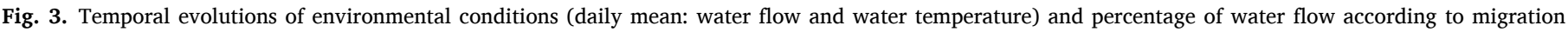
routes (bypass, gate, microturbine and main turbines HPP). 
Table 1

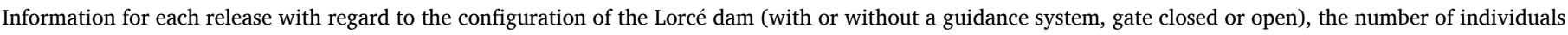
released and detected near the bypass and the passage metrics of the bypass.

\begin{tabular}{|c|c|c|c|c|c|c|c|c|c|}
\hline Release & $\mathrm{N}$ & Guidance System & Gate open & Mercury lamp & $\mathrm{N}$ detected & $\mathrm{N}$ In trap & Attraction Efficiency (\%) & Overall Efficiency (\%) & Adjusted efficiency (\%) \\
\hline 1 & 300 & - & - & $\mathrm{x}$ & 70 & 32 & 23.3 & 10.7 & 45.4 \\
\hline 2 & 300 & - & $\mathrm{x}$ & $\mathrm{x}$ & 76 & 34 & 25.3 & 11.7 & 44.7 \\
\hline 3 & 300 & $\mathrm{x}$ & - & $\mathrm{x}$ & $134-188^{\mathrm{a}}$ & 97 & $44.7-62.7^{\mathrm{b}}$ & 32.3 & $72.4-51.6^{c}$ \\
\hline
\end{tabular}

${ }^{\text {a }}$ Number of individuals detected at the antenna at the entrance of guidance system.

b Attraction efficiency corrected: $\mathrm{N}$ detected at the entrance of guidance system / N released.

c Adjusted efficiency corrected: $\mathrm{N}$ in trap / $\mathrm{N}$ detected at the entrance of guidance system.
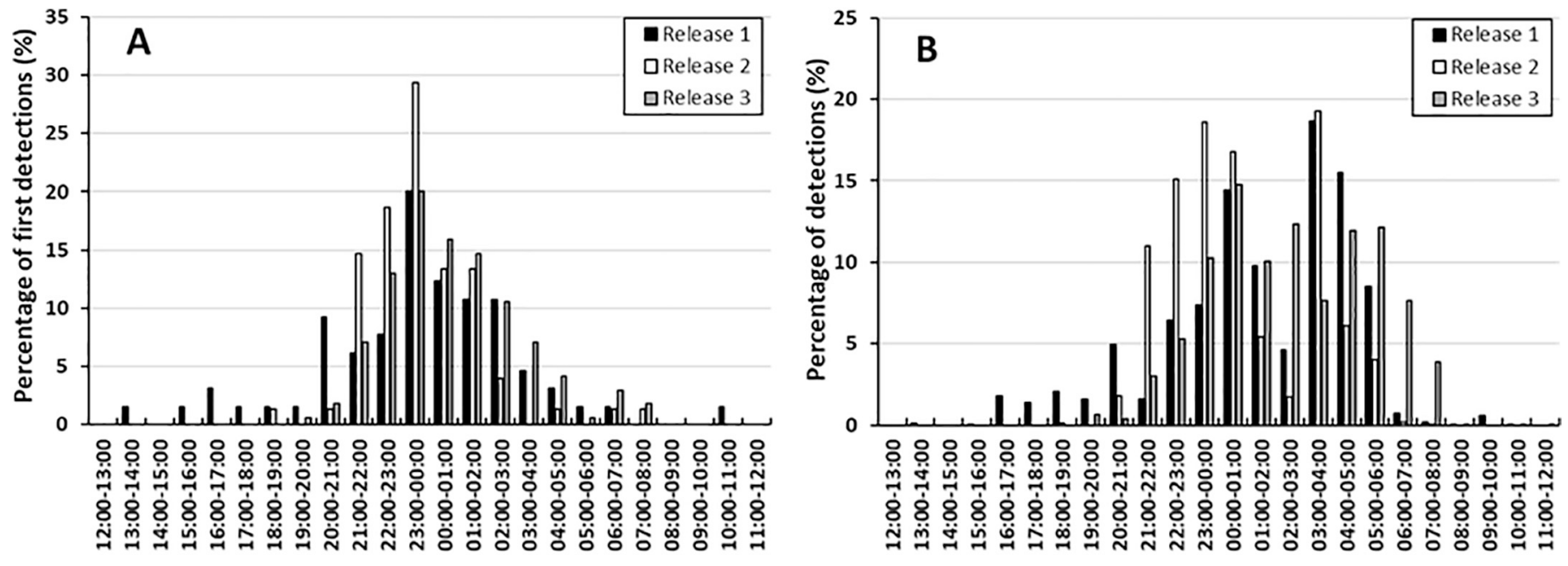

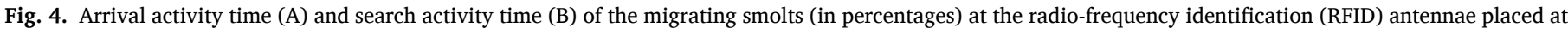
the entrance of the downstream migration bypass.
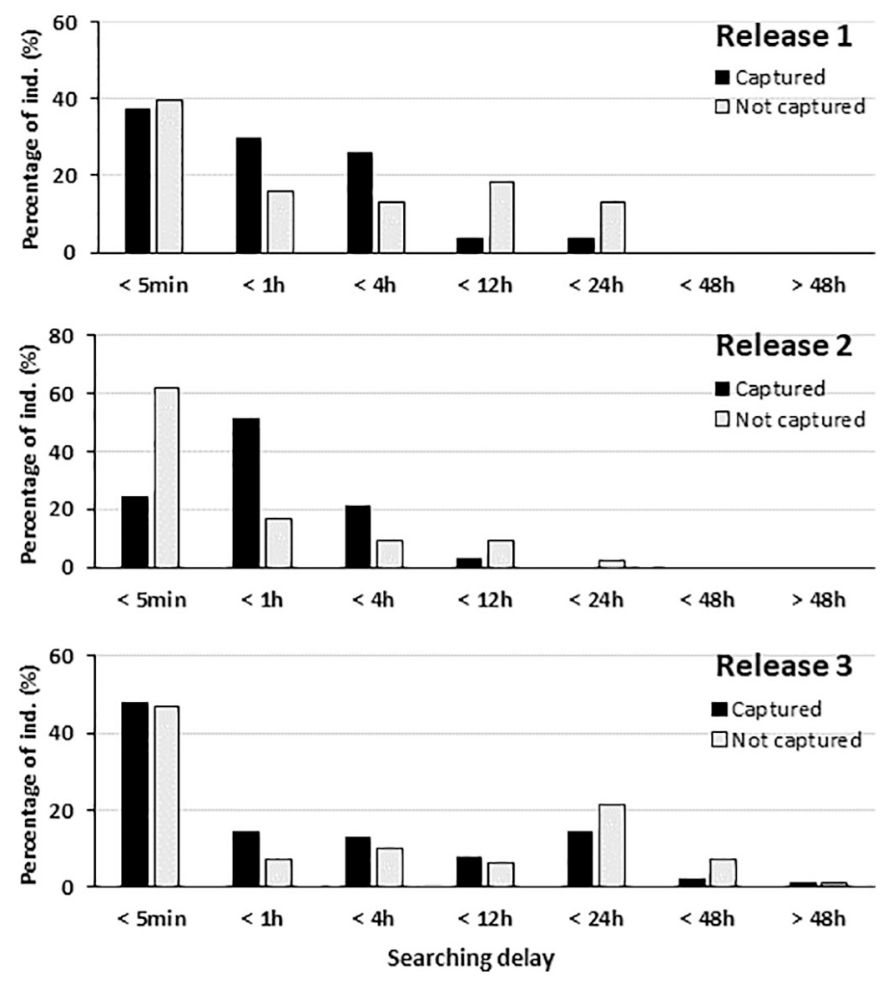

Fig. 5. Searching delay (time between the first and the last detection) by the individual (ind.) smolts at the entrance of the downstream migration bypass during each release event. migration route and that 26 smolts were no longer detected. Among the smolts that were not detected at the entrance of the bypass, $31(10.3 \%)$ used the mobile gate as a migration route and were detected at the end of the bypassed river section and $44(14.7 \%)$ were detected in the tailrace. Among the smolts with an identified migration route and taking into account the impact of the bypassed river section and the theoretical mortality rates of turbines, $16.5 \%$ used the bypass, $39.8 \%$ the main turbines and $43.7 \%$ the mobile gate. There was no difference in smolts' fork length among the three potential migration routes for detected/ captured individuals (KW test: $\chi^{2}=0.52 ; p=0.77$ ).

During release 3 (Fig. 6), among the 300 smolts, 188 (62.7\%) were detected at the entrance of the guidance system of the bypass and 97 $(32.3 \%)$ used the bypass as migration route; $32(10.6 \%)$ were further detected at the end of the bypassed river section. Thirteen (4.3\%) smolts that approached the bypass and were not captured in the trap were finally detected at the end of the bypassed river section and used the microturbine as a migration route. Thirteen (4.3\%) smolts that approached the bypass were finally detected in the tailrace. This means that at least $13.8 \%$ of the smolts that approached the bypass finally changed their migration route and that 65 smolts were no longer detected. Among the smolts that were not detected at the entrance of the bypass, $12(4 \%)$ used the microturbine as a migration route and were detected at the end of the bypassed river section and 17 (5.6\%) were detected in the tailrace. Among the smolts with an identified migration route and taking into account the impact of the BRS and the theoretical mortality rates of turbines, $43.5 \%$ used the bypass, $36.3 \%$ the microturbine and $20.2 \%$ the main turbine. There was no difference in smolts' fork length among the three potential migration routes (KW test: $\chi^{2}=$ $1.73 ; p=0.42$ ).

From the release site to the arrival at the Lorce dam (distance 3.75 $\mathrm{km}$ ), the median migration speed of the smolts was $3.12 \mathrm{~km} \mathrm{day}^{-1}$. The migration speed of the smolts between the release site $(3.75 \mathrm{~km}$ 


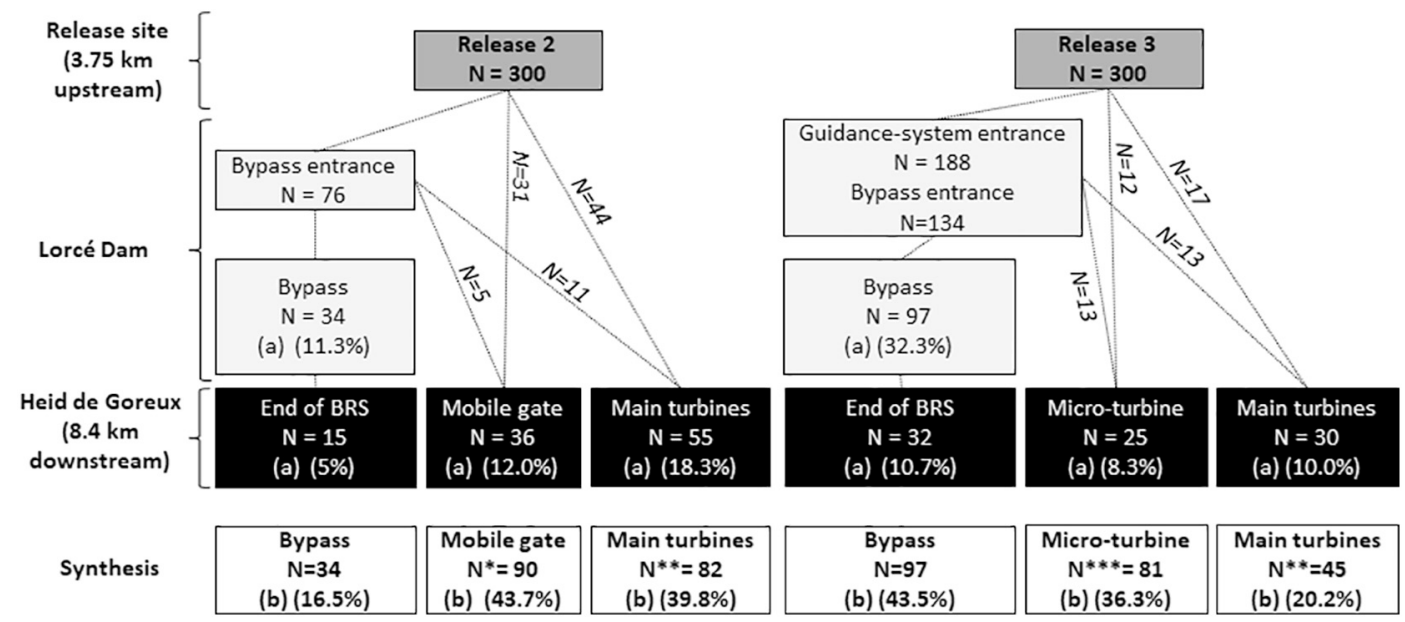

Fig. 6. Detection data and migration routes for releases 2 and 3 with (a) the percentage of individuals captured/detected compared to the total tagged and (b) the percentage of corrected number of individuals per migration route. BRS: bypassed river section. $\mathrm{N}^{*}$ : estimated number of individuals that used the mobile gate as a migration route with the impact of the BRS (loss rate $=60 \%$ ). $\mathrm{N}^{* *}$ : estimated number of individuals that use main turbines as a migration route with its theoretical mortality rate (loss rate $=31 \%$ ). $\mathrm{N}^{* * * *}$ : estimated number of individuals that use micro-turbine as a migration route with the impact of the BRS and its theoretical mortality rate (loss rate $=23.3 \%$ ).

upstream of the Lorcé dam) and the Heid de Goreux hydroelectric power station ( $8.4 \mathrm{~km}$ downstream of the Lorcé dam) varied significantly between migration routes, from $3.44 \mathrm{~km} \mathrm{day}^{-1}$ (microturbine) to $7.42 \mathrm{~km}$ day $^{-1}$ (Francis turbines) (KW test, $p<0.0001$, Table 2). The passage through the Francis turbines via the forced pipelines was, as expected, significantly faster than the other migration routes (Wilcoxon tests, all $p$ $<0.05$ ). The release tests in the bypassed river section (only $42.5 \%$ detected at the end of the bypassed river section) generated a median speed between $1.96 \mathrm{~km} \mathrm{day}^{-1}$ (3.8 km downstream Lorcé dam) and $6.06 \mathrm{~km}$ day $^{-1}$ (5.8 $\mathrm{km}$ downstream of the Lorcé dam). The global median speed in the bypassed river section was $2.99 \mathrm{~km}^{-1}{ }^{-1}$. The smolts that used the bypass showed a significantly lower speed (Wilcoxon test, $p<0.001)$ in the bypassed river section $(8.4 \mathrm{~km})$ compared with the total section (release site to Heid de Goreux: $12.15 \mathrm{~km}$ ). Downstream of the study site (34 km), from Heid de Goreux to Méry (Fig. 1), 25 smolts were recaptured during the trap monitoring at Méry (Ourthe River), with a median speed of $8.00 \mathrm{~km} \mathrm{day}^{-1}$. The speed of smolts in the Heid de Goreux-Méry section was significantly higher (Wilcoxon tests, all $\mathrm{p}$ $<0.05$ ) than the bypassed river section and the total section (the release site to Heid de Goreux is $12.15 \mathrm{~km}$ ).

Table 2

Migration speed of the smolts in different river sections.

\begin{tabular}{|c|c|c|c|}
\hline River section & $\begin{array}{l}\text { Distance } \\
\text { travelled }(\mathrm{km})\end{array}$ & $\mathrm{N}$ & $\begin{array}{l}\text { Speed }\left(\mathrm{km} \mathrm{day}^{-1}\right) \\
\text { Median Range }\end{array}$ \\
\hline Release site to the Lorcé dam & 3.75 & 334 & $3.120 .26-12.5$ \\
\hline \multicolumn{4}{|l|}{ Release site to Heid de Goreux } \\
\hline $\begin{array}{l}\text { Through Francis turbines and } \\
\text { forced pipelines }\end{array}$ & 7.25 & 92 & $7.421 .27-20.43$ \\
\hline $\begin{array}{l}\text { Through gate (release } 2 \text { ) and } \\
\text { bypassed river section }\end{array}$ & 12.15 & 36 & $4.951 .30-19.00$ \\
\hline $\begin{array}{l}\text { Through microturbine (release } \\
\text { 3) and bypassed river section }\end{array}$ & 12.15 & 38 & $3.441 .87-21.89$ \\
\hline $\begin{array}{l}\text { Through bypass and bypassed } \\
\text { river section }\end{array}$ & 12.15 & 47 & $3.640 .91-9.24$ \\
\hline \multicolumn{4}{|l|}{$\begin{array}{l}\text { Release tests in bypassed river } \\
\text { section }\end{array}$} \\
\hline $\begin{array}{l}0.05 \mathrm{~km} \text { downstream of Lorcé } \\
\text { dam }\end{array}$ & 8.35 & 36 & $3.370 .89-16.70$ \\
\hline $\begin{array}{l}3.8 \mathrm{~km} \text { downstream of Lorcé } \\
\text { dam }\end{array}$ & 4.6 & 18 & $1.961 .03-9.38$ \\
\hline $\begin{array}{l}5.8 \text { km downstream of Lorcé } \\
\text { dam }\end{array}$ & 2.6 & 31 & $6.091 .05-11.77$ \\
\hline $\begin{array}{l}\text { Heid de Goreux to Méry in the Ourthe } \\
\text { river }\end{array}$ & 34 & 25 & $8.003 .29-28.00$ \\
\hline
\end{tabular}

\section{Discussion}

The re-establishment of secure and uninterrupted downstream migration for fish species is a major challenge in any highly fragmented river system, especially when old hydropower stations have to be equipped with retrofitted fish-friendly devices and when multiple migration routes (safe and unsafe) are offered. It requires efficient downstream facilities (bypass, rack protection system, fish-friendly turbine, gate opening, etc.) that must be adapted to the configuration of each hydroelectric site (e.g. river flow, type and location of intake racks, power and location of turbines, presence or absence of a bypassed river section and types of opening gates, among other factors) to optimize searching behaviour of the target species. This study highlighted the migration routes used by smolts at a complex hydroelectric station and showed the possibility to significantly increase the attraction and the performance of a retrofitted downstream bypass, functioning at nonoptimal low flow, by the placement of a guidance system at the entrance. The device increased the proportion of smolts that used a safe route to continue their downstream migration, even though the proportion of smolts that used the turbines is still too high. This finding underlines the importance to conduct field studies in real conditions, to better understand the process of selection of a specific migration route by individual smolts, to increase the efficiency of the protection devices and/or mitigation measures (Kärgenberg et al., 2020; Renardy et al., 2020). However, the study of the choice of the migration routes in the field is logistically difficult and is strongly influenced by uncontrolled variables - such as changes in environmental conditions (e.g. flow and temperature), the modes of electricity production and the physiological state of the fish - among the release events, making the establishment of rigorous methodological conditions to allow unbiased comparisons sometimes quite complicated.

Among the diverse set of methods suitable for field analysis of migration at hydropower stations, biotelemetry is recognized as an efficient tool (Ovidio et al., 2017a, b 2020; Wilkes et al., 2018a). Depending on the research budget, the size of the fish, the environment, the objectives in terms of sampling effort and the degree of details on searching behaviour, several methods can be used: presence/absence or 2D and 3D acoustic telemetry (e.g. Silva et al., 2018, 2020), manual or automatic radio telemetry (e.g. Renardy et al., 2020) or RFID technology (e.g. Tomanova et al., 2017, 2018). In this study, in a medium-sized river, we used antennae connected to automatic RFID stations to identify the migration routes associated with RFID tags; this approach allows 
tagging of small-sized individuals in relevant quantities. In combination with a trapping system, the RFID system was adequate and performed globally, even though a large proportion of released smolts were not detected. This lack of detections can be explained by different factors: (i) mortality due tagging or due to predation; ii) absence of migration stimulation of released smolts; (iii) chance of tag collision as smolts migrated in group and some individuals may pass at the same moment through the antennae; and (iv) non-optimal functioning of the antennae and/or absence of detection when smolts pass through larger antennae due to high speed/depth or in a suboptimal position to be detected. We voluntarily worked under low flow environmental conditions, which are restrictive for passage at hydropower stations, and the most restrictive in terms of passage success, even though this may decrease the smolts stimulation to migrate. Hence, the results obtained in this study do not represent a complete vision of what would have happened during the entire migration season of smolts in the Amblève River, especially under more important flow conditions. Finally, we used hatchery smolts, but as observed by Karppinen et al. (2014), Renardy et al. (2020) and Larinier et al. (2020), they remain highly sensitive to the environmental cues that trigger fish migration. However, Larocque et al. (2020) observed differences in survival between wild and hatchery smolts (better for wild) during downstream migration in a Lake Ontario tributary. In our study, the impossibility to work with wild populations did not allow us to investigate whether behavioural responses when approaching the hydropower station would differ from those expected in wild smolts.

In our study site, with a $7 \mathrm{MW}$ hydroelectric power plant, the monitored bypass operated at a discharge $<0.6 \%$ of the maximum flow turbine, which is quite low and far below the minimum best recommendation practices (Johnson et al., 2005; Courret and Larinier, 2008). The quantification of the downstream bypass performance without the guidance system revealed a minimum attraction efficiency of $23.3 \%$ and a minimum overall efficiency of $10.7 \%$ and $11.7 \%$. In terms of adjusted bypass passage efficiency, we observed that $44.7 \%$ and $45.7 \%$ of the smolts that approached the entrance of the bypass entered inside and were captured in the floating smolt trap. These performances are similar to those previously observed in the same study site with drome and mercury lamp placement tests (Ovidio et al., 2017a). Adding the guidance system, without any change in the functioning flow, significantly increased the attraction efficiency to $44.7 \%$, the minimum overall efficiency to $32.3 \%$ and the adjusted efficiency to $72.4 \%$. This last value is the most indicative as it only concerns the smolts that really approached the bypass and is not influenced by an absence of migration or the loss of a part of the released smolts. Atlantic salmon smolts typically adopt head first position when migrating downstream but can turn tail first under turbulent and high flow conditions, thereby greatly decreasing guidance efficiency (Haro et al., 1998). Visual observations clearly showed the reticence and hesitation of smolts when approaching the bypass, mostly in the absence of guidance system, changing their body orientation against the flow with retreat behaviour, during which the fish moved in and out of hydrodynamic areas just at the entrance of the bypass near the dropping point. The guidance system enlarged the pre-entrance zone and induced a best flow velocity gradient (as suggested by Enders et al., 2009), which changed the behaviour of the smolts when approaching the bypass, with less reticence and hesitation to enter, with some still orienting their body against the flow but many more in the flow direction, passing head first. It is however difficult to affirm whether the metallic composition of the guidance system, which strongly reflects the mercury lighting, is better or not for the attractiveness of the bypass. Haro et al. (1998) observed that maintenance of positive rheotaxis and strong swimming behaviour along the bypass system were important factors in bypass effectiveness. Previous studies have already mentioned lower overall bypass passage minimum efficiency rates $(5 \%-28 \%$ : Chanseau et al., 1999; Gosset and Travade, 1999; Fjeldstad et al., 2012; Larinier et al., 2020) and some similar efficiency to our study (32\%, Croze, 2008; 33\%: Chanseau et al., 2002; 37.1\%: Bosc et al., 2016 in Tomanova et al., 2018). However, the most recent studies have quantified best performance ranging from $55 \%$ to $100 \%$ (reviewed in Tomanova et al., 2018). The main problems in our study site are the protection rack with too large bar space $(41 \mathrm{~mm})$ offering low protection for migrating fish from entering turbines and the ratio between the functioning flow and the proportion of maximum turbined discharge, which is very low. An improvement of the performance of the bypass would benefit from an increase of the functioning discharge and a reduction of the bar space at the protection rack.

More than $69.1 \%$ of the migrating smolt stayed less than $1 \mathrm{~h}$ near the entrance of the bypass before entering or searching for another passageway, and a small portion of the smolts (0.6\%) sometimes stayed more than 2 days before passing. These search times are similar to those observed by Tomanova et al. (2018), with a median searching delay from 10 to $54 \mathrm{~min}$, and Renardy et al. (2020), with a median of $58 \mathrm{~min}$. Smolts need to pass without delay, hereby highlighting the importance of the first smolt movement trajectory at the approach of a hydropower station to be as fish-friendly as possible and to enable safe and rapid passage to avoid energy loss due to prolonged searching behaviour, as well as to avoid increased predation risk. In terms of approaching behaviour at the nycthemeral scale (24-h period), our results largely support that Atlantic salmon smolts mainly arrive during crepuscular and night periods near the entrance (peak at 23:00 $\mathrm{h}$ to 00:00 h). These findings are consistent with previous studies showing darkness migration in smolts (Jonsson, 2005; McCormick et al., 1998; Scruton et al., 2007; Ovidio et al., 2017a; Kärgenberg et al., 2020; Renardy et al., 2020).

The percentage of migration routes used by the smolts was quite different depending on the two tested configurations. During release 2 in the absence of the guidance system but with an open mobile gate - the most used migration route was the mobile gate (43.7\%) followed by the main turbine (39.8\%) and the bypass (16.5\%). The bypass performance was quite similar to release 1 , but the opening of a mobile gate enabled a non-negligible additional part of the smolts to migrate safely, even if the central gate is not located in the best spot to attract the smolts. Depending on the configuration, spillway gates may represent an useful and safe alternative migration route for downstream-migrating smolts (Coutant and Larinier, 2000; Katopodis and Williams, 2012; Ducan et al., 2018). Moreover, an increase in water discharge towards the spillway gates favours passage through this migration route (Nyqvist et al., 2016). In this configuration, the order of the utilized migration routes is in accordance with the gradient of proportion of water discharge supplied, as has been observed by some authors (Hvidsten and Johnsen, 1997; Serrano et al., 2009; Fjelstad et al., 2014; Havn et al., 2020). In the configuration with the guidance system and the mobile gate closed (release 3 ), the most used migration route was the bypass $(43.5 \%)$ followed by the micro-turbine $(36.3 \%)$ and the main turbines (20.2\%). In this configuration, the bypass, which has the least functioning discharge, becomes the most attractive migration route; these results indicate a real improvement of its intrinsic performance. Some authors had already observed that the route with the most important discharge is not always the most used (Havn et al., 2017; Haraldstad et al., 2018; Kärgenberg et al., 2020; Renardy et al., 2020). Unfortunately, the bar rack spacing in our study $(41 \mathrm{~mm})$ did not prevent smolts entering the influence zone of the main and microturbine intake zone, contrary to a 10-15 $\mathrm{mm}$ bar spacing that may prevent fish from entering (Havn et al., 2017; Thorstad et al., 2017).

It is important to set ecologically realistic targets for passage effectiveness at barriers considering the diversity of life histories, swimming abilities and spatial ecologies (Wilkes et al., 2018, 2018b). For diadromous migratory species, whose critical habitats are clearly separated in space, it can be assumed that passage efficiencies should be greater than for the 'non-migratory' species (Wilkes et al., 2018, 2018b). To have a complete overview of the entire hydroelectric site, we must consider that the theoretical mortality rate of the main turbines and the microturbine is, respectively, $31 \%$ and $23.3 \%$ (according to Larinier and Travade, 1999). Of note, the obligation to use the $8.4 \mathrm{~km}$ bypassed river 
section after the passage of the bypass and the mobile gate seems to be problematic because the escapement rate of this impacted river stretch was quite low (mean $=40 \%$ ). This would be due to predation by birds (Jepsen et al., 2019; Källo et al., 2020) like great cormorants and herons that are abundant in this river basin, but also by predatory fish (Kekäläinen et al., 2008) in low water level and flow conditions, which increase the visibility and the efficacy for predation. The bypassed river section may also force the smolts to spend more energy to swim and to find the current veins in the river (Gauld et al., 2013) and this was associated with reduced migration speed in our study. This highlights the importance of implementation of ecological flows (Eflows) in degraded river sections consistent with the achievement of the environmental objectives of the Water Framework Directive in natural surface water bodies (European Commision 2015). The ecological flow downstream of the dam of Lorcé is not sufficient to allow an efficient downstream migration of smolts. During low or medium flow conditions that were tested, and considering the impact of the BRS and the passage through turbines in our study site, the potential success of passage at the Lorcé dam is not sufficient in terms of salmon conservation at the scale of the entire Meuse River basin. Indeed, the Atlantic salmon smolt stage has a reduced physiological time to reach the sea, and any additional time may cause important risks (McCormick et al., 1998). The cumulative impact of the succession of multiple hydropower stations on downstream migration may be considerable and is a major problem for smolts that have to travel long distances in rivers (Thorstad et al., 2012, 2017). After passing the Lorcé dam, the smolts have to migrate $386 \mathrm{~km}$ before reaching the North Sea. The migration speeds observed in our study site were quite low $\left(<8 \mathrm{~km} \mathrm{day}^{-1}\right.$ ) and may be problematic for the rest of the travel because some major trouble sites in the main course of the Meuse may continue to slow down the smolts (Verbiest et al., 2012; Brevé et al., 2014). In disturbed river sections, there have been various smolt migration speeds reported $(2.4,10.6,13.8,44.9$ and $67.2 \mathrm{~km}$ day $^{-1}$; Stich et al., 2015; Newton et al., 2019; Renardy et al., 2020). In undisturbed river sections, the migration speed may reach 72.6-129.6 $\mathrm{km} \mathrm{day}^{-1}$ (Thorstad et al., 2004; Stich et al., 2015) but may be considerably lower in some cases (6.4 $\mathrm{km} \mathrm{day}^{-1}$; Newton et al., 2019).

In conclusion, our results underline the difficulty of installing a bypass system at an old existing hydropower plant, for which nothing was planned for fish protection during the first operation in 1932. A best trade-off between electricity production and smolt protection during their downstream migration must be considered. Indeed, despite its significant improvement due to the placement of the guidance system, the downstream bypass must be accompanied by other measures to increase the passage success of the smolts: i) a smaller spacing of the bar rack (ii) a partial opening of a mobile gate; iii) implementing ecological flows in the river section downstream of the HPP (i.e. Eflows); (v) increase of the functioning flow of the bypass; and vi) shutdown of the microturbine and the main turbines during the night period. This last management measure could be facilitated by the existence of a predictive model of smolts' downstream migration in the Meuse River basin at the spring season scale, which will enable effective targeting of this measure (Teichert et al., 2020). The Lorcé Dam has been equipped with an operational upstream fish pass since 2007 (Benitez et al., 2015), and thus we hope that in the future this site will go from a fish-hostile to a fish-friendly ecological status. This type of research is critical to improve fish passage technologies and to minimise potential negative repercussions of hydroelectric facilities.

Supplementary data to this article can be found online at https://doi. org/10.1016/j. ecoleng.2021.106148.

\section{Declaration of Competing Interest}

None

\section{Acknowledgments}

Financial support for this study was provided by the Public Service of Wallonia General Operational Direction of Agriculture, Natural Resources and Environment, Non-Navigable Watercourses. Séverine Renardy received a Ph.D. research grant from FRIA-FNRS. We thank the hydroelectric power plant owners for their kind collaboration during the experiments. Thanks to two anonymous reviewers for their valuable comments on the first draft of the manuscript.

\section{References}

Albayrak, I., Kriewitz, C.R., Hager, W.H., Boes, R.M., 2018. An experimental investigation on louvres and angled bar racks. J. Hydraul. Res. 56 (1), 59-75.

Benitez, J.P., Nzau Matondo, B., Dierckx, A., Ovidio, M., 2015. An overview of potamodromous fish upstream movements in medium-sized rivers, by means of fish passes monitoring. Aquat. Ecol. 49, 481-497.

Brackley, R., Lucas, M.C., Thomas, R., ADams, C.E., Bean, C.W., 2018. Comparison of damage to live v. euthanized Atlantic salmon (Salmo salar) smolts from passage through an Archimedean screw turbine. J. Fish Biol. 92, 1635-1644.

Brevé, N., Vis, H., Spierts, I., de Laak, G., Moquette, F., Breukelaar, A., 2014. Exorbitant mortality of hatchery-reared Atlantic salmon smolts (Salmo salar L.), in the Meuse river system in the Netherlands. J. Coast. Conserv. 18, 97-109.

Buysse, D., Mouton, A.M., Baeyens, R., Coeck, J., 2015. Evaluation of downstream migration mitigation actions for eel at an Archimedes screw pump pumping station. Fish. Manag. Ecol. 22, 286-294.

Calles, O., Karlsson, S., Hebrand, M., Comoglio, C., 2012. Evaluating technical improvements for downstream migrating diadromous fish at a hydroelectric plant. Ecol. Eng. 48, 30-37.

Chanseau, M., Larinier, M., Travade, F., 1999. Efficacité d'un exutoire de dévalaison pour smolts de saumon atlantique (Salmo salar L.) et comportement des poissons au niveau de l'aménagement hydroélectrique de Bedous sur le gave d'aspe étudiés par la technique de marquage recapture et par radiotélémétrie. Bull. fr. pêche piscic 353 (354), 99-120.

Courret, D., Larinier, M., 2008. Guide pour la conception de prises d'eau «ichtyocompatibles » pour les petites centrales hydroelectriques. Rapport Ghaappe RA 08-04. Ademe 72.

Coutant, C.C., Whitney, R.R., 2000. Fish behavior in relation to passage through hydropower turbines: A review. Trans. Am. Fish. Soc. 129, 351-380.

Duncan, J.P., Deng, Z.D., Arnold, J.L., Fu, T., Trumbo, B.A., Carlson, T.J., Zhou, D., 2018. Physical and ecological evaluation of a fish-friendly surface spillway. Ecol. Eng. 110, $107-116$.

European Commision (2015). Ecological flows in the implementation of the Water Framework Directive. Guidance document ${ }^{\circ} 31 ., 106$ p.

Fjeldstad, H.P., Uglem, I., Diserud, O.H., Fiske, P., Forseth, T., Kvingedal, E. Järnegren, J., 2012. A concept for improving Atlantic salmon (Salmo salar) smolt migration past hydro power intakes. J. Fish Biol. 81, 642-663.

Fjeldstad, H.P., Alfredsen, K., Boissy, T., 2014. Optimising Atlantic salmon smolt survival by use of hydropower simulation modelling in a regulated river. Fish. Manag. Ecol. 21, 22-31.

Fjeldstad, H.P., Pulg, K.U., Forseth, T., 2018. Safe two-way migration for salmonids and eel past hydropower structures in Europe: a review and recommendations for bestpractice solutions. Mar. Freshw. Res. 69, 1834-1847.

Fullerton, A.H., Burnett, K.M., Steel, E.A., Flitcroft, R.L., Pess, G.R., Feist, B.E., Sanderson, B.L, 2010. Hydrological connectivity for riverine fish: measurement challenges and research opportunities. Freshw. Biol. 55, 2215-2237.

Gauld, N.R., Campbell, R.N.B., Lucas, M.C., 2013. Reduced flow impacts salmonid smolt emigration in a river with low-head weirs. Sci. Total Environ. 458-460, 435-443.

Gosset, C., Travade, F., 1999. Devices to aid downstream salmonid migration: behavioral barriers. Cybium 23, 45-66.

Haraldstad, T., Forseth, T., Höglund, E., 2018. Common mechanisms for guidance efficiency of descending Atlantic salmon smolts in small and large hydroelectric power plants. River Res. Appl. 34, 1179-1185.

Haro, A., Odeh, M., Noreika, J., Castro-Santos, T., 1998. Effect of water acceleration on downstream migratory behavior and passage of atlantic salmon smolts and juvenile american shad at surface bypasses. Trans. Am. Fish. Soc 127, 118-127.

Havn, T.B., Sæther, S.A., Thorstad, E.B., Teichert, M.A.K., Heermann, L., Diserud, O.H., $\varnothing$ kland, F., 2017. Downstream migration of Atlantic salmon smolts past a low head hydropower station equipped with Archimedes screw and Francis turbines. Ecol. Eng. 105, 262-275.

Havn, T.B., Thorstad, E.B., Borcherding, J., Heermann, L., Teichert, M.A.K., Ingendahl, D., Tambets, M., Sæther, S.A., Økland, F., 2020. Impacts of a weir and power station on downstream migrating Atlantic salmon smolts in a German river. River Res. Appl. 36, 784-796.

Huet, M., 1949. Aperçu des relations entre la pente et les populations piscicoles des eaux courantes. Aquatic Sciences-Research Across Boundaries 11, 332-351.

Hvidsten, N.A., Johnsen, B.O., 1997. Screening of descending Atlantic salmon (Salmo salar L.) smolts from a hydropower intake in the river Orkla. Norway. Nord. J. Freshw. Res. 73, 44-49.

Jepsen, N., Flávio, H., Koed, A., 2019. The impact of Cormorant predation on Atlantic salmon and Sea trout smolt survival. Fish. Manag. Ecol. 26, 183-186. 
Johnson, G.A., Steven, M.A., Noah, S.A., Timothy, O.W., 2005. Evaluation of a prototype surface flow bypass for juvenile salmon and steelhead at the powerhouse of Lower Granite Dam, Snake River, Washington, 1996-2000. N. Am. J. Fish Manag. 25, 138-151.

Källo, K., Baktoft, H., Jepsen, N., Aerestrup, K., 2020. Great cormorant (Phalacrocorax carbo sinensis) predation on juvenile down-migrating trout (Salmo trutta) in a lowland stream. ICES J. Mar. Sci. 77 (2), 721-729.

Kärkenberg, E., Thorstad, E.B., Järvekülg, R., Sandlun, O.T., Saadre, E., Økland, F., Thalfeldt, M., Tambets, M., 2020. Behaviour and mortality of downstream migrating Atlantic salmon smolts at a small power station with multiple migration routes. Fish. Manag. Ecol 27, 32-40.

Karppinen, P., Jounela, P., Huusko, R., Erkinaro, J., 2014. Effects of release timing on migration behaviour and survival of hatchery-reared Atlantic salmon smolts in a regulated river. Ecol. Freshw. Fish 23, 438-452.

Katopodis, C., Williams, J.G., 2012. The development of fish passage research in a historical context. Ecol. Eng. 48, 8-18.

Kekäläinen, J.E., Niva, T., Huuskonen, H., 2008. Pike predation on hatchery-reared Atlantic salmon smolts in a northern Baltic river. Ecol. Freshw. Fish 17, 100-109.

Klopries, E.M., Deng, Z.D., Lachmann, T.U., Schüttrumpf, H., Trumbo, B.A., 2018. Surface bypass as a means of protecting downstream migrating fish: lack of standardised evaluation criteria complicates evaluation of efficacy. Mar. Freshw. Res. 69, 1882-1893.

Larinier, M., 2001. Environmental issues, Dams and fish migration. In: Marmulla, G. (Ed.), FAO fisheries technical paper: Vol. 419 Dams, fish and Fisheries: Opportunities, challenges and conflict resolution, pp. 45-89.

Larinier, M., Travade, F., 1999. The development and evaluation of downstream bypasses for juvenile salmonids at small hydroelectric plants in France. In: Odeh, M. (Ed.), Fish Passage Technology. American Fisheries Society, Bethesda, MD.

Larinier, M., Travade, F., 2002. Downstream migration: problems and facilities. Bull. fr. pêche piscic. $364,181-207$.

Larinier, M., Dumond, L., Larrigue, T., Frey, A., Travade, F., 2020. Performance of a large partial-depth guide wall to divert downstream migrating Atlantic salmon smolts at Tuilières Dam, Dordogne River. Knowl. Manag. Aquat. Ecosyst. 421, 15.

Laroque, S.M., Johnson, T.B., Fisk, A.T., 2020. Survival and migration patterns of naturally and hatchery-reared Atlantic salmon (Salmo salar) smolts in a Lake Ontario tributary using acoustic telemetry. Freshw. Biol. https://doi.org/10.1111/ fwb.13467.

Marohn, L., Prigge, E., Reinhol, H., 2014. Escapement success of silver eels from a German river system is low compared to management-based estimates. Freshw. Biol. $59,64-72$.

Marschall, E.A., Mather, M.E., Parrish, D.L., Allison, G.W., McMenemy, J.R., 2011. Migration delays caused by anthropogenic barriers: Modeling Dams, temperature, and success of migrating salmon smolts. Ecol. Appl. 21, 3014-3031.

McCormick, S.D., Hansen, L.P., Quinn, T.P., Saunders, R.L., 1998. Movement, migration, and smolting of Atlantic salmon (Salmo salar). Can. J. Fish. Aquat. Sci. 55, 77-92.

Newton, M., Barry, J., Dodd, J.A., Lucas, M.C., Boylan, P., ADams, C.E., 2019. A test of the cumulative effect of river weirs on downstream migration success, speed and mortality of Atlantic salmon (Salmo salar) smolts: an empirical study. Ecol. Freshw. Fish 28, 176-186.

Nunn, A.D., Cowx, I.G., 2012. Restoring river connectivity: prioritizing passage improvements for diadromous fishes and lampreys. Ambio 41, 402-409.

Nyqvist, D., Greenberg, L.A., Goerig, E., Calles, O., Bergman, E., Ardren, W.R., CastroSantos, T., 2016. Migratory delay leads to reduced passage success of Atlantic salmon smolts at a hydroelectric Dam. Ecol. Freshw. Fish 26, 707-718.

Ovidio, M., Philippart, J.C., 2002. The impact of small physical obstacles on upstream movements of six species of fish: Synthesis of a 5-year telemetry study in the River Meuse basin. Hydrobiologia 483, 55-69.

Ovidio, M., Dierckx, A., Bunel, S., Grandry, L., Spronck, C., Benitez, J.P., 2017a. Poor performance of a retrofitted downstream bypass revealed by the analysis of approaching behaviour in combination with a trapping system. River Res. Appl. 33, 27-36.

Ovidio, M., Sonny, D., Dierckx, A., Watthez, Q., Bourguignon, S., de le Court, B., Detrait, O., Benitez, J.P., 2017b. The use of behavioural metrics to evaluate fishway efficiency. River Res. Appl. 33, 1484-1493.

Ovidio, M., Sonny, D., Watthez, Q., Goffaux, D., Detrait, O., Orban, P., Nzau Matondo, B. Renardy, S., Dierckx, A., Benitez, J.P., 2020. Evaluation of the performance of successive multispecies improved fishways to reconnect a rehabilitated river. Wetl. Ecol. Manag. 28, 641-654.

Parrish, D.L., Behnke, R.J., Gephard, S.R., Mc Cormick, S.D., Reeves, G.H., 1998. Why aren't there more Atlantic salmon (Salmo salar)? Can. J. Fish. Aquat. Sci. 55, $281-287$.
Pauwels, I.S., Baeyens, R., Toming, G., Schneider, M., Buysse, D., Coeck, J., Thutan, J.A., 2020. Multi-species assessment of injury, mortality and physical conditions during downstream passage through a large Archimedes hydrodynamic screw (Albert canal, Belgium). Sustainability $12,8722$.

Philippart, J.C, Micha, J.C, Baras, E., Prignon, C., Gillet A., Joris, S. 1994. The Belgian Project "Meuse Salmon 2000". First results, Problems and Future prospects. Water Sci Technol. 29, 315-317.

Piper, A.T., Rosewarne, P.J., Wright, R.M., Kemp, P.S., 2018. The impact of an Archimedes screw hydropower turbine on fish migration in a lowland river. Ecol. Eng. 118, 31-42.

Renardy, S., Benitez, J.P., Tauzin, A., Dierckx, A., Nzau Matondo, B., Ovidio, M., 2020. How and where to pass? Atlantic salmon smolts behaviour at a hydropower station offering multiple migration-routes. Hydrobiologia 847, 469-485.

Scruton, D.A., McKinley, R.S., Kouwen, N., Eddy, W., Booth, R.K., 2003. Improvement and optimization of fish guidance efficiency (FGE) at a behavioural fish protection system for downstream migrating Atlantic salmon (Salmo salar) smolts. River Res. Appl. 19, 605-617.

Scruton, D.A., Pennell, C.J., Bourgeois, C.E., Goosney, R.F., Porter, T.R., Clarke, K.D., 2007. Assessment of a retrofitted downstream fish bypass system for wild Atlantic salmon (Salmo salar) smolts and kelts at a hydroelectric facility on the Exploits River, Newfoundland, Canada. Hydrobiologia 582, 155-169.

Serrano, I., Rivinoja, P., Karlsson, L., Larsson, S., 2009. Riverine and early marine survival of stocked salmon smolts, Salmo salar L., descending the Testebo River, Sweden. Fish. Manag. Ecol. 16 (5), 386-394.

Silva, A.T., Lucas, M.C., Castro-Santos, T., Katopodis, C., Baumgartner, L.J., Thiem, J.D., Burnett, N.J., 2018. The future of fish passage science, engineering, and practice. Fish Fish. 19, 340-362.

Silva, A.T., Bærum, K.M., Hedger, R.D., Baktoft, H., Fjeldstat, H.P., Gjelland, K.Ø, Økland, F., Forseth, T, 2020. The effects of hydrodynamics on the three-dimensional downstream migratory movement of Atlantic salmon. Sci. Total Environ. 705, 135773.

Stich, D.S., Kinnisson, M.T., Kocik, J.F., Zydlewski, J.D., 2015. Initiation of migration and movement rates of Atlantic salmon smolts in fresh water. Can. J. Fish. Aquat. Sci. 72 (9), 1339-1351.

Teichert, N., Benitez, J.P, Dierckx, A., Tétard, S., de Oliveira, E., Trancart, T., Feunteun, E., Ovidio, M., 2020. Development of an accurate model to predict the phenology of Atlantic salmon smolt spring migration. Aquat. Conserv. 30, 1552-1565.

Tétard, S., Maire, A., Lemaire, M., De Oliveira, E., Martin, P., Dominique, C., C., 2019. Behaviour of Atlantic salmon smolts approaching a bypass under light and dark conditions: Importance of fish development. Ecol. Eng. 131, 39-52.

Thorstad, E., Finstad, B., Sivertsgrd, R., Bjorn, P., McKinleyd, R., 2004. Migration speeds and orientation of Atlantic salmon and sea trout post-smolts in a Norwegian fjord system. Environ. Biol. Fish 71, 305-311.

Thorstad, E.B., Whoriskey, F., Uglem, I., Moore, A., Rikardsen, A.H., Finstad, B., 2012. A critical life stage of the Atlantic salmon (Salmo salar): Behaviour and survival during the smolt and initial post-smolt migration. J. Fish Biol. 81, 500-542.

Thorstad, E.B., Havn, T.B., Sæther, S.A., Heermann, L., Teichert, M.A.K., Diserud, O.H., $\varnothing$ kland, F., 2017. Survival and behaviour of Atlantic salmon smolts passing a run-ofriver hydropower facility with a movable bulb turbine. Fish. Manag. Ecol. 24, 199-207.

Tomanova, S., Courret, D., Alric, A., 2017. Protecting fish from entering turbines: the efficiency of a low-sloping rack for downstream migration of Atlantic salmon smolts. Houille Blanche 1, 11-13.

Tomanova, S., Courret, D., Alric, A., Oliveira, E., Lagarrigue, T., Tétard, S., 2018. Protecting efficiently sea-migrating salmon smolts from entering hydropower plant turbines with inclined or oriented low bar spacing racks. Ecol. Eng. 122, 143-152.

Verbiest, H., Breukelaar, A., Ovidio, M., Philippart, J.C., Belpaire, C., 2012. Escapement success and patterns of downstream migration of female silver eel Anguilla anguilla in the river Meuse. Ecol. Freshw. Fish 21, 395-403.

Wilkes, M.A., Webb, J.A., Pompeu, P.S., Silva, L.G.M., Vowles, A.S., Baker, C.F., Franklin, P., Link, O., Kemp, P.S., 2018. Not just a migration problem: Metapopulations, habitat shifts, and gene flow are also important for fishway science and management. River Res. Appl. 35, 1688-1696.

Wilkes, M.A., Baumgartner, L., Boys, C., Silva, L.G.M., O'Connor, J., Jones, M., Stuart, I., Habit, E., Link, O., Webb, J.A., 2018b. Fish- Net: Probabilistic models for fishway planning, design and monitoring to support environmentally sustainable hydropower. Fish Fish 19, 677-697. 